\title{
Perencanaan Pembangunan Lepas Pantai: Strategi Pembangunan Berkelanjutan di Teluk Jakarta Melalui Pembangunan Waduk Lepas Pantai
}

\author{
Angga Sukmara Christian Permadi ${ }^{1}$ \\ Chaikal Amrullah ${ }^{2}$ \\ Frieda Astrianty Hazet $^{3}$ \\ Unika Merlin Sianturi ${ }^{4}$ \\ Abdul Malik Sadat Idris ${ }^{5}$
}

Kementerian Perencanaan Pembangunan Nasional/Bappenas - Indonesia

\begin{abstract}
Abstraksi
Permasalahan ibukota semakin hari semakin meningkat dimana permasalahan tersebut meliputi berbagai aspek, baik sosial, ekonomi maupun lingkungan. Untuk menyelesaikan permasalahan tersebut dibutuhkan solusi yang tidak hanya mampu mengatasi masalah tetapi juga dapat mengembangkan potensi Jakarta. Selain itu, solusi penyelesaian tersebut harus mampu mendukung tercapainya pembangunan kota Jakarta yang berkelanjutan yang mengacu pada pencapaian target Sustainable Development Goals (SDGs) 2015-2030. Salah satu langkah yang diambil dari permasalahan tersebut adalah perencanaan pembangunan Waduk Lepas Pantai yang diusulkan sebagai solusi holistik dan berkelanjutan dari permasalahan yang dihadapi di Teluk Jakarta. Dalam Konsep Waduk Lepas Pantai direncanakan akan dibangun tanggul sepanjang $\pm 50,6 \mathrm{~km}$ pada kedalaman mencapai -20 m membentang dari Muara Sungai Cisadane (Provinsi Banten) sampai Muara Gembong (Provinsi Jawa Barat). Tanggul tersebut akan menciptakan sistem pertahanan banjir yang andal, kolam tampungan dan pengolah air baku, dan sekaligus pengembangan kawasan pesisir di Teluk Jakarta.
\end{abstract}

Kata Kunci: waduk lepas pantai, teluk Jakarta, dan kawasan pesisir

\footnotetext{
1 Angga Sukmara Christian Permadi adalah Staff Manajemen Banjir di Direktorat Pengairan dan Irigasi Kementerian Perencanaan Pembangunan Nasional/Bappenas Republik Indonesia. Email: anggasukmara08@gmail.com

${ }^{2}$ Chaikal Amrullah adalah Tenaga Ahli Junior Direktorat Pengairan dan Irigasi Kementerian Perencanaan Pembangunan

Nasional/Bappenas Republik Indonesia.

$\stackrel{s}{s}$ Frieda Astrianty Hazet adalah Fungsional Perencana Muda Direktorat Pengairan dan Irigasi Kementerian Perencanaan Pembangunan

Nasional/Bappenas Republik Indonesia.

${ }^{4}$ Unika Merlin Sianturi, Staff Perencana Direktorat Pengairan dan Irigasi Kementerian Perencanaan Pembangunan Nasional/Bappenas Republik Indonesia.

${ }_{5}^{5}$ Abdul Malik Sadat Idris adalah Direktur Pengairan dan Irigasi Kementerian Perencanaan Pembangunan Nasional/Bappenas Republik Indonesia.
} 
Angga Sukmara Christian Permadi, Chaikal Amrullah, Frieda Astrianty Hazet, Unika Merlin Sianturi, dan Abdul Malik Sadat Idris

\title{
Perencanaan Pembangunan Lepas Pantai: Strategi Pembangunan Berkelanjutan di Teluk Jakarta melalui Pembangunan Waduk Lepas Pantai
}

\author{
Angga Sukmara Christian Permadi \\ Chaikal Amrullah \\ Frieda Astrianty Hazet \\ Unika Merlin Sianturi \\ Abdul Malik Sadat Idris
}

\section{Pendahuluan}

Menangani permasalahan Ibukota yang kompleks salah satu strategi yang relevan dalam pembangunan yang berkelanjutan adalah dengan membangun Waduk Lepas Pantai di kawasan pesisir Jakarta, yaitu di daerah Teluk Jakarta. Waduk Lepas Pantai merupakan satu kesatuan sistem yang terdiri dari saluran transversal (saluran penampung aliran sungai), kolam retensi untuk menampung air banjir, kolam air baku, sistem pemompaan, kolam pelabuhan dan kanal akses nelayan ke laut, pintu air, spillway, dan dilengkapi dengan sistem rekayasa hidrolika. Sistem rekayasa hidrolika akan menyinergikan saluran transversal dengan kolam tampungan air untuk menjaga kualitas air sesuai dengan standar mutu air baku ataupun standar buangan limbah ke laut lepas dengan cara kualitas airnya diperbaiki melalui WTP (Water Treatment Plant) sehingga memenuhi standar mutu air.. Waduk Lepas Pantai ini juga akan memanfaatkan potensi aliran Sungai Cisadane dimana kualitas Sungai Cisadane cukup baik dan kuantitasnya cukup besar sehingga dapat meningkatkan potensi volume air baku yang dapat diperoleh dari pembangunan Waduk Lepas Pantai. Waduk lepas pantai yang direncanakan akan menampung semua aliran sungai yang bermuara di teluk Jakarta bukan hanya sungai Cisadane. Aliran Sungai Cisadane akan ditampung bersama dengan aliran sungai lainnya ke dalam kolam retensi yang selanjutnya diolah menjadi sumber air baku Jakarta melalui mekanisme tata kelola air.

Dalam konsep pembangunan berkelanjutan di Teluk Jakarta, perolehan tampungan air baku tidak dilakukan dengan pembebasan lahan melainkan dengan menciptakan kolam yang sangat luas (mencapai $\pm 22.758 \mathrm{Ha}$ ) dengan luasan kolam air baku mencapai $\pm 12.126 \mathrm{Ha}$. Kolam tampungan air baku diperoleh bukan dengan mekanisme pembebasan lahan melainkan melalui penurunan muka air eksisting sehingga timbul daratan baru. Pemanfaatan kolam air baku/air bersih ini tentu saja memerlukan studi lebih lanjut dan harus terintegrasi dengan program-program Pemerintah terkait penyediaan air baku dan pengembangan sistem sanitasi terpusat (Jakarta Sewerage System) yang saat ini dalam tahap perencanaan. Selain untuk memenuhi kebutuhan air baku, Waduk Lepas Pantai juga mempunyai fungsi sebagai bagian dari sistem perlindungan banjir. Waduk Lepas Pantai terbagi dalam beberapa segmen yang terpisah oleh kanal. Diperlukan pemisahan yang jelas antara kolam tampungan air tawar dan kolam tampungan air banjir.

Kolam lepas pantai dibentuk oleh tanggul lepas pantai yang berfungsi sebagai tanggul lepas pantai yang memiliki bagian untuk kolam air baku dan kolam tampungan air banjir. Kolam air baku merupakan kolam yang menampung air 
Angga Sukmara Christian Permadi, Chaikal Amrullah, Frieda Astrianty Hazet, Unika Merlin Sianturi, dan Abdul Malik Sadat Idris

sungai yang telah diolah di IPAL (Instalasi Pembuangan Air Limbah) yang disalurkan melalui saluran transversal dan kualitas airnya telah memenuhi syarat sebagai air baku untuk diproses sebagai air minum sehingga dalam sistem waduk lepas pantai, air hanya diolah hingga mencapai kualitas air baku, sedangkan pengolahan hingga menjadi air minum diserahkan kepada PAM Jaya atau PDAM. Untuk memproses air di kolam air baku dibutuhkan Waste Water Treatment Plant (WWTP) yang dibangun terintegrasi dengan kolam air baku. Sedangkan, kolam tampungan air banjir didasari oleh kajian selama kondisi banjir, dimana air sungai dialirkan ke kolam tampungan air banjir dan/atau dialirkan langsung ke laut lepas melalui kanal. Elevasi air di Kanal akses nelayan tidak difungsikan untuk mengalirkan air banjir. Dalam kolam tampungan air banjir atau juga disebut dengan kolam air kotor tidak boleh melebihi elevasi $5 \mathrm{~m}$ di bawah HWL (High Water Level) ${ }^{6}$. Ketika muka air di kolam banjir (kolam air kotor) $>5 \mathrm{~m}$ di bawah HWL, air di dalam kolam banjir akan dipompa ke laut sehingga elevansi kolam dibatasi hingga $5 \mathrm{~m}$ dari MSL (Mean Sea Level). Pada bagian kolam tampungan air banjir (kolam air kotor), harus dilakukan pengerukan atau penyedotan sedimen secara berkala sehingga volume tampungannya dapat dipertahankan dan cukup untuk menampung air dalam rentang waktu terjadinya banjir. Berdasar permasalahan yang kompleks di ibukota, maka pembangunan Waduk Lepas Pantai menjadi salah satu solusi bagi permasalahan air baku dan penampungan air banjir (kolam air kotor) yang ada di Jakarta.

\section{Landasan Konseptual}

Kajian mengenai Strategi Pembangunan Berkelanjutan di Teluk Jakarta Melalui Waduk Lepas Pantai secara konseptual didasari oleh River Bank Filtration (RBF), Wetland, dan Rawa buatan (artificial wetland/constructed wetland). River Bank Filtration (RBF) adalah teknologi untuk mengolah air sungai dengan memancing air sungai untuk berpindah ke sumur-sumur pompa di daerah akuifer untuk selanjutnya diolah pada Slow Sand Filtration (SSF). Penentuan peletakan sumur pompa menentukan proses mixing dan reduce dari kontaminan tersebut. Air yang sudah bersih dari kontaminan kemudian dipompa untuk digunakan sebagai air minum (Ray and Jain, 2011).160Sebelum membangun sumur-sumur pompa diperlukan studi secara mendalam untuk menentukan daerah pengambilan air. Hal ini dipengaruhi oleh hidrogeologi lokal dan hidrologi sungai. Terdapat tiga parameter penentu keberhasilan RBF, yaitu: kondisi sungai, komposisi tanah dan akuifer, serta lokasi sumur pompa. Untuk menghindari clogging, RBF harus diletakkan di daerah transport sedimen.

Selain RBF, landasan selanjutnya yang digunakan dalam kajian mengenai Strategi Pembangunan Berkelanjutan di Teluk Jakarta Melalui Waduk Lepas Pantai adalah Wetland. Wetland adalah sistem yang termasuk pengolahan alami, dimana terjadi aktivitas pengolahan sedimentasi, filtrasi, transfer gas, adsorpsi, pengolahan kimiawi dan biologis, karena aktivitas mikroorganisme dalam tanah dan aktivitas tanaman (Metcalf \& Eddy, 1993). Sistem pengolahan wetland adalah sistem rekayasa yang telah didesain dan dibangun dengan memanfaatkan proses alamiah yang melibatkan tumbuhan, tanah, dan kumpulan mikroba yang saling berhubungan untuk membantu pengolahan limbah cair. (Vymazal, 1998).

${ }^{6}$ Bila $5 \mathrm{~m}$ d bawah HWL berarti dibawah air laut, sangat kecil dan jarang digunakan istilah $5 \mathrm{~m}$ dibawah HWL 
Angga Sukmara Christian Permadi, Chaikal Amrullah, Frieda Astrianty Hazet, Unika Merlin Sianturi, dan Abdul Malik Sadat Idris

Melengkapi RBF dan Wetland sebagai landasan konseptual kajian mengenai Strategi Pembangunan Berkelanjutan di Teluk Jakarta Melalui Waduk Lepas Pantai adalah Rawa Buatan. Rawa buatan (artificial wetland/constructed wetland) merupakan sebuah kompleks rancangan manusia yang terdiri dari substrat, tanaman, hewan, dan air yang meniru rawa alami untuk kegunaan dan keuntungan manusia (Hammer, 1989).

\section{Metodelogi}

Metode penelitian yang digunakan dalam kajian mengenai Strategi Pembangunan Berkelanjutan di Teluk Jakarta Melalui Waduk Lepas Pantai adalah kualitatif yang berdasar observasi lapang dan lebih menitikberatkan pada bentuk FGD (Focus Group Discussion). FGD merupakan suatu kegiatan eksplorasi suatu permasalahan maupun isu khusus dari diskusi suatu kelompok yang berfokus pada aktivitas bersama diantara para individu yang terlibat didalam kegiatan tersebut untuk menghasilkan suatu jawaban ataupun menemukan solusi bersama untuk disepakati (Kitzinger dan Barbour, 1999). Pada dasarnya FGD bertujuan untuk mengumpulkan data mengenai berbagai pandangan peserta terhadap suatu permasalahan yang dibahas. Melengkapi pemahaman tersebut, Krueger (1988) menjelaskan bahwa dalam FGD digunakan mekanisme pertanyaan terbuka yang bertujuan mencari data serta pandangan dan jawaban yang disertai dengan penjelasan.

Lehoux, Poland, \& Daudelin (2006) memaparkan keunggulan penggunaan FGD, yaitu mampu memberikan data yang lebih banyak dan dapat memberikan nilai tambah pada data yang tidak diperoleh ketika menggunakan metode pengumpulan data lainnya. Menambahkan pemahaman Lehoux, Poland, \& Daudelin, Krueger (1988) menjelaskan bahwa FGD biasanya dilakukan beberapa kali. Oleh karena itu, FGD pasti dilakukan dalam beberapa tahap agar dapat memperoleh data yang mendalam dan lebih kaya.

\section{Hasil, Analisis, dan Diskusi}

\subsection{Tata Kelola Air}

Pengendalian masalah banjir dan rob di DKI Jakarta merupakan salah satu kegiatan prioritas Pemerintah Provinsi DKI Jakarta. Upaya yang sudah dilakukan oleh Pemerintah Provinsi DKI Jakarta untuk pengendalian banjir antara lain pembangunan Kanal Banjir Timur yang ditujukan untuk mengurangi banjir di kawasan Timur dan Utara Jakarta ( \pm seperempat dari luas keseluruhan Kota Jakarta) dan Kanal Banjir Barat. Dengan adanya Kanal Banjir Timur dan Barat tersebut, potensi terjadinya banjir dapat diminimalisir. Kegiatan lain yang juga terus dilakukan adalah normalisasi sungai dan pemeliharaan saluran drainase.

Dalam mengendalikan banjir, prinsip dasar yang digunakan oleh Pemerintah DKI Jakarta adalah mengalirkan air sungai yang masuk ke Jakarta melalui pinggir kota dan langsung ke laut. Tujuannya adalah agar air yang datang dari daerah hulu di atas Jakarta tidak memasuki wilayah tengah Kota Jakarta, tetapi dialirkan langsung menuju laut melalui Kanal Banjir Barat dan Cengkareng Drain di bagian Barat dan di bagian Timur melalui Kanal Banjir Timur dan Cakung Drain.

Prinsip tata kelola air yang sudah diterapkan oleh Pemerintah DKI Jakarta sebenarnya sudah dapat dikatakan sesuai dengan kaidah pengelolaan manajemen air, namun perlu dilakukan penambahan rekayasa teknik untuk membuat upaya tersebut menjadi efektif. Konsep Pembangunan Waduk Lepas Pantai ini akan 
Angga Sukmara Christian Permadi, Chaikal Amrullah, Frieda Astrianty Hazet, Unika Merlin Sianturi, dan Abdul Malik Sadat Idris

mengakomodasi tata kelola air yang efektif untuk DKI Jakarta dalam rangka mengurangi intensitas banjir yang terjadi di Jakarta. Usulan solusi tata kelola air yang ditawarkan tidak terlepas dari tata kelola air existing dan konsep Waduk Lepas Pantai secara keseluruhan. Pertama aliran di permukaan perlu dialirkan secara efektif ke sungai atau badan penerima air utama, yaitu:

(a) Kanal Banjir Barat, menampung aliran air dari Kali Ciliwung dan Kali Krukut, dan Sungai Cideng

(b) Kanal Banjir Timur, menampung aliran air dari Kali Cakung, Kali Jatikramat, Kali Buaran, Kali Sunter, dan Kali Cipinang

(c) Cengkareng Drain, menampung aliran air dari Sungai Pasanggrahan, Kali Angke dan Kali Mookervart. Sementara yang masuk wilayah Tangerang adalah Sungai Cisadane yang melalui Pintu Air Tangerang masuk ke Cengkareng Drain.

(d) Cakung Drain, menampung aliran air dari Kali Jatikramat, Kali Cakung, dan Kali Buaran.

Aliran air dari ke-empat badan penerima air utama tersebut keseluruhannya bermuara ke saluran transversal sebelum masuk ke kolam retensi pada Waduk Lepas Pantai. Secara umum saluran transversal berfungsi sebagai penghubung atau penyalur air sungai yang bermuara ke Teluk Jakarta ke Kola, namun saluran transversal juga dapat berfungsi sebagai long storage.

\subsubsection{Aliran Sungai pada Kondisi Air Normal}

Dalam keadaan normal, air sungai masuk ke saluran transversal yang elevasinya lebih rendah dari muka air sungai sehingga dapat mengalir secara gravitasional. Selanjutnya, air pada saluran transversal dialirkan ke dalam kolam retensi untuk kemudian diolah di fasilitas pengolahan air di hilir sampai memenuhi baku mutu kelas II untuk selanjutnya masuk ke kolam air baku. Volume kolam air baku disesuaikan dengan kebutuhan air baku yang diperlukan oleh PAM Jaya dan kebutuhan air untuk industri, perkotaan dan rumah tangga di DKI Jakarta dan kawasan sekitarnya.

Pada keadaan ini, pintu air yang berada di saluran transversal akan dibuka sehingga aliran air dari sungai langsung masuk ke kolam retensi. Penetapan lokasi pengolahan air yang berasal dari sungai akan ditentukan ditahap pendetailan desain. Kemudian untuk menjaga tinggi muka air di kolam retensi, air akan dibuang ke laut menggunakan pompa. 


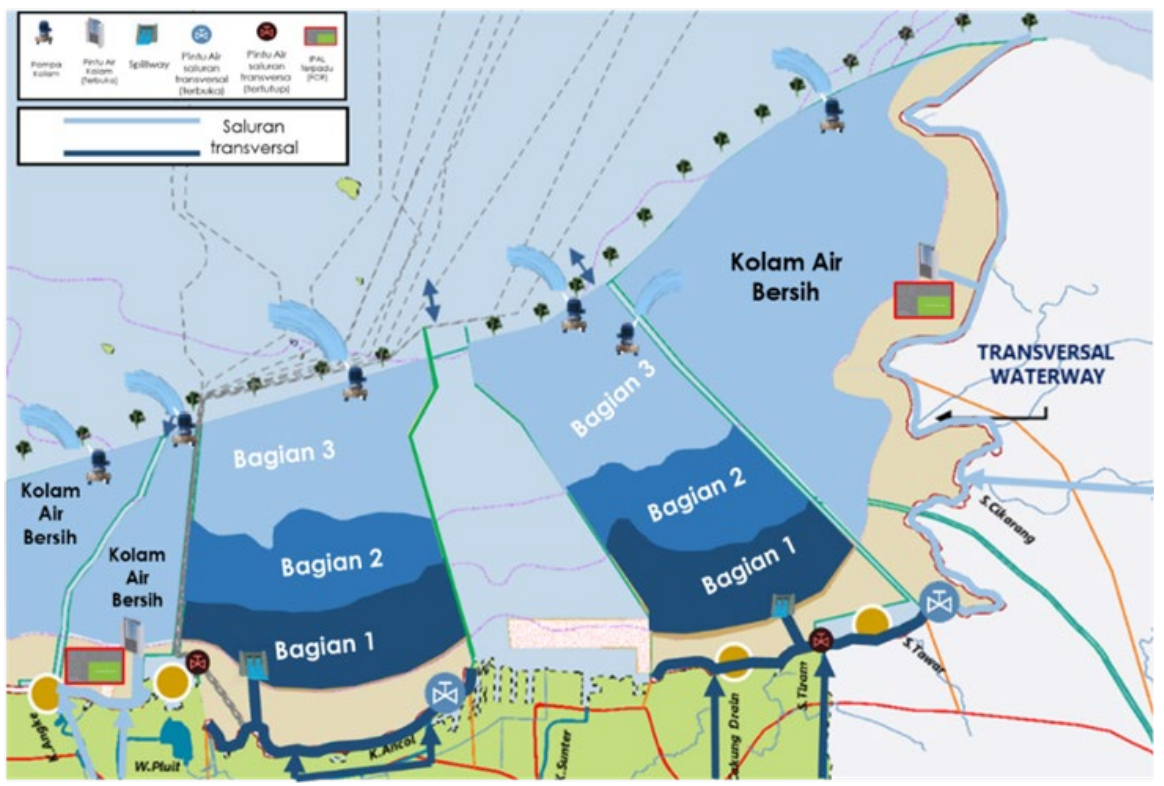

Gambar 1. Tata Kelola Air dalam Konsep Waduk Lepas Pantai Sumber: Direktorat Pengairan dan Irigasi Bappenas

\subsubsection{Aliran Sungai pada Kondisi Debit Banjir}

Saat debit air banjir, air sungai dialirkan langsung ke laut lepas melalui kanal nelayan dan juga dialirkan masuk ke kolam retensi banjir untuk selanjutnya dipompa ke laut. ${ }^{7}$ Di bagian udik dan hilir saluran transversal akan dipasang pintu air dimana pintu ini akan ditutup saat air banjir. Pintu air hanya dipasang pada bagian tertentu, tidak di hulu dan hilir saluran transversal. Selain itu, di kolam labuh nelayan akan dipasang pintu air dimana pintu air ini akan dibuka saat air sungai dapat mengalir secara gravitasional ke laut. Di spillway dari kolam retensi (air banjir) akan dipasang pintu air dimana pintu air ini akan dibuka saat air banjir sehingga air sungai dapat mengalir ke kolam retensi (air banjir) secara gravitasional.

\subsection{Pemenuhan Kebutuhan Air Baku}

\subsubsection{Water Demand untuk Kebutuhan Domestik dan Industri}

Proyeksi suplai air untuk kebutuhan domestik ditetapkan dari standar konsumsi air per kapita berdasarkan ketentuan Kementerian PUPR yang diselaraskan dengan populasi dan target rasio pelayanan. Sedangkan untuk kebutuhan industri dilakukan dengan menambahkan proyeksi permintaan air ke volume penggunaan saat ini. Permintaan tambahan air untuk industri berasal dari luas lahan industri dan permintaan air per unit. Mengacu pada perencanaan dasar kawasan industri yang ada dalam studi JABODETABEK MPA, permintaan air saat ini ditetapkan sebesar $35 \mathrm{~m}^{3} /$ hari per sektor area industri.

\footnotetext{
${ }^{7}$ Air sungai tidak akan dialirkan melalui kanal nelayan. Air sungai yang masuk kedalam kolam aat kondisi banjir akan dipompa ke laut lepas
} 
Angga Sukmara Christian Permadi, Chaikal Amrullah, Frieda Astrianty Hazet, Unika Merlin Sianturi, dan Abdul Malik Sadat Idris

Tabel 1. Proyeksi Kebutuhan Air Tahun 2010-2030

\begin{tabular}{|c|c|c|c|c|c|c|c|}
\hline \multirow{3}{*}{ Area } & \multirow{3}{*}{$\begin{array}{c}\text { Jenis } \\
\text { Kebutuhan }\end{array}$} & \multicolumn{6}{|c|}{ Proyeksi Kebutuhan Air (ms detik) } \\
\hline & & \multicolumn{3}{|c|}{ Studi MPA, 2012} & \multicolumn{3}{|c|}{ Studi Decathlon, 2018} \\
\hline & & 2010 & 2020 & 2030 & 2010 & 2020 & 2030 \\
\hline \multirow{2}{*}{ Banten } & Domestik & 1,9 & 7,3 & 14,6 & \multirow{2}{*}{14,53} & \multirow{2}{*}{18,28} & \multirow{2}{*}{20,76} \\
\hline & Industri & 5,1 & 5,7 & 7 & & & \\
\hline \multirow{2}{*}{$\begin{array}{c}\text { DKI } \\
\text { Jakarta }\end{array}$} & Domestik & 16,2 & 26,4 & 36,3 & \multirow{2}{*}{27,58} & \multirow{2}{*}{33,28} & \multirow{2}{*}{37,83} \\
\hline & Industri & 2,4 & 2,4 & 5,3 & & & \\
\hline \multirow[t]{2}{*}{ Jawa Barat } & Domestik & 5,4 & 16,2 & 30,9 & \multirow{2}{*}{30,04} & \multirow{2}{*}{37,98} & \multirow{2}{*}{44,9} \\
\hline & Industri & 9,8 & 12 & 15,9 & & & \\
\hline \multicolumn{2}{|c|}{ Total Domestik } & 23,5 & 49,9 & 81,8 & \multirow{2}{*}{72,15} & \multirow{2}{*}{89,54} & \multirow{2}{*}{103,49} \\
\hline \multicolumn{2}{|c|}{ Total Industri, Komersil } & 17,3 & 20,1 & 28,2 & & & \\
\hline \multicolumn{2}{|c|}{ Total Kebutuhan } & 40,8 & 70 & 110 & 72,15 & 89,54 & 103,49 \\
\hline
\end{tabular}

Studi Jabodetabek Metropolitan Priority Area (MPA):

a) Jawa Barat mencakup Bekasi, Karawang, Bogor

b) Perhitungan Kebutuhan Air Studi MPA tidak mencakup kebutuhan untuk komersil

Studi Decathlon:

a) Jawa Barat mencakup Bekasi, Cianjur, Bogor, Depok

b) Perhitungan Kebutuhan Air Studi Decathlon mencakup kebutuhan Domestik, Industri dan Komersil

Berdasarkan studi MPA JICA (2012) dan studi Decathlon (2018), kebutuhan pasokan air bersih DKI Jakarta hingga tahun 2030 masing-masing sebesar 41,6 m /det dan 37,83 m³/det. Sedangkan kebutuhan air untuk Megapolitan Banten - DKI -Jabar diprediksi mencapai $103 \mathrm{~m}^{3} / \operatorname{det}$ (Studi Decathlon) atau 110 $\mathrm{m}^{3} /$ det (Studi MPA JICA). Suplai existing air bersih dari sistem penyediaan air minum perpipaan yang disediakan oleh PDAM hanya $18 \mathrm{~m}^{3} /$ det untuk DKI Jakarta sehingga dibutuhkan suplai air baku tambahan sebesar 23,6 $\mathrm{m}^{3} / \operatorname{det}$ pada tahun 2030 sehingga terjadi defisit antara pasokan dan kebutuhan. Defisit air ini dipenuhi oleh warga dengan pengambilan air tanah. Pengambilan air tanah secara berlebihan menyebabkan terjadinya penurunan muka tanah dan intrusi air laut.

Berdasarkan rencana penyediaan suplai air PAM Jaya untuk Jakarta, pada tahun 2030 suplai air yang dapat disediakan oleh PAM Jaya adalah sebesar 35,5 $\mathrm{m}^{3} /$ detik dimana suplai air ini berasal dari pembangunan IPA Pesanggrahan, IPA Pejaten, IPA Hutan Kota, IPA Tirta Benteng, IPA Buaran III, SPAM Jatiluhur $1 \&$ 2, dan SPAM Karian. Di lain pihak sumber air dari Jatiluhur juga dibutuhkan oleh Jawa Barat dan Tangerang terlebih lagi banyaknya daerah industri dan munculnya kawasan perumahan baru. Untuk itu diperlukan perumusan solusi bagi keterbatasan air baku untuk wilayah Jabodetabek area yang salah satunya melalui pembangunan waduk penampungan air baku di laut. 
Angga Sukmara Christian Permadi, Chaikal Amrullah, Frieda Astrianty Hazet, Unika Merlin Sianturi, dan Abdul Malik Sadat Idris

\subsubsection{Potensi Ketersediaan Air}

Dengan adanya waduk lepas pantai diharapkan dapat meningkatkan potensi ketersediaan air dalam mengatasi masalah keterbatasan air baku untuk mendukung pencapaian SDGs. Melalui pembangunan waduk lepas pantai dapat tersedia reservoir untuk air baku sebesar $\pm 1,6$ milyar $\mathrm{m}^{3}$ dan danau retensi seluas $\pm 8.300 \mathrm{Ha}$ dengan volume sebesar $\pm 831,5$ juta $\mathrm{m}^{3}$. Alternatif penyediaan air lainnya adalah melalui pemanenan air hujan (rainwater harvesting) dan water reuse/water recycle.

Peraturan mengenai sumber air alternatif di DKI Jakarta sudah ada namun butuh ditegakkan. Potensi water harvesting di DKI Jakarta diprediksi dapat memberikan tambahan supply air baku sebesar 2,37 - 4,75 m3/detik. Best practice terkait penggunaan water recycle adalah Plaza Indonesia, yang membutuhkan 2.200meter kubik setiap harinya, dengan 1.500-meter kubik (70\%) dihasilkan dari sistem water recycle. Kemajuan teknologi dapat dimanfaatkan untuk mengurangi kebocoran air (Non-Revenue Water/NRW), me-recycle air limbah menjadi air baku, uprating instalasi pengolah air yang mempunyai suplai air baku yang mencukupi, dan merencanakan biaya desalinasi (sea water reverse osmosis) menjadi lebih murah.

\subsubsection{Peningkatan Kualitas Air}

a. Pengurangan Beban Pencemar di wilayah Hulu dan Tengah

Pengurangan beban pencemar di wilayah hulu dan tengah dilakukan melalui pengolahan air limbah komunal, komersial (in-situ), individual domestik, dan manajemen limbah industri dan limbah padat.

\section{Sanitasi Komunal}

Pada daerah dengan kepadatan penduduk tinggi yang belum terlayani oleh sistem terpusat, lahan untuk septic tank sangat sulit dijumpai. Sebuah sistem komunal adalah sistem air limbah kecil untuk masyarakat dengan 100-5.000 rumah tangga, dengan jaringan pengumpulan limbah dan pengolahan pabrik sendiri. Untuk mencapai standar BOD dan fosfat yang dibutuhkan, tempat pengolahan ini harus memiliki efisiensi pengurangan BOD dan fosfat yang tinggi.

\section{Peningkatan Sanitasi On-Site}

Fasilitas on-site saat ini sebagian besar terdiri dari septic tank dengan efisiensi penghilangan BOD yang rendah (estimasi oleh rencana induk JICA sekitar $30 \%$ ) karena hanya dikosongkan ketika sudah penuh. Pada daerah yang masih akan menggunakan sistem ini, kampanye partisipasi komunitas perlu dilaksanakan, dengan menggunakan basis data yang memetakan kondisi septic tank di komunitas tersebut. Basis data ini digunakan untuk identifikasi septic tank yang membutuhkan renovasi, dan sebagai dasar untuk penyedotan rutin oleh PT PAL JAYA dan sektor swasta. Jika belum tersedia, maka akan dibangun Instalasi Pengelola Lumpur Tinja (IPLT). Dengan mengintegrasikan jasa penyedotan dan kunjungan ke IPLT ke basis data, pembuangan ilegal lumpur tinja ke air permukaan bisa diminimalisir.

\section{Manajemen Limbah Industri}

Semua industri bertanggung jawab secara hukum untuk mengolah air limbah sebelum dibuang ke air limbah permukaan. Untuk mencapai hal ini, mereka harus bersama-sama atau sendiri-sendiri membangun dan mengoperasikan IPAL mereka sendiri, dan melaporkan setiap bulan tentang volume dan kualitas pembuangan mereka ke Badan Pengelolaan Lingkungan Hidup Daerah (BPLHD). 
Angga Sukmara Christian Permadi, Chaikal Amrullah, Frieda Astrianty Hazet, Unika Merlin Sianturi, dan Abdul Malik Sadat Idris

Dalam praktiknya banyak industri, terutama yang kecil tidak memiliki atau tidak mengoperasikan fasilitas mereka. BPLHD tidak memiliki sumber daya yang dibutuhkan untuk memeriksa kebenaran laporan.

Untuk mengusahakan agar industri kecil dan rumah tangga memenuhi tanggung jawab mereka, program partisipasi perlu dilaksanakan, dimulai dengan kampanye kesadaran, termasuk pemberian insentif untuk pembangunan fasilitas pengolahan bersama atau individu. Kepatuhan industri menengah dan besar hanya dapat dicapai melalui peningkatan penegakan hukum. Sumber daya manusia dan dana yang memadai harus tersedia untuk BPLHD, untuk memantau akurasi dari laporan yang diterima dan menindaklanjuti secara hukum bila diperlukan.

\section{Manajemen Sampah Padat}

Untuk menghentikan pembuangan sampah padat ke air permukaan, cakupan pengumpulan sampah penuh (100\%) harus terpenuhi, yang dapat dilaksanakan melalui peningkatan personil dan peralatan pengumpulan sampah yang tersedia, didukung oleh pembangunan tiga Instalasi Pengolahan Sampah Regional (Nambo di Bogor, Ciupecang di Tangerang dan Bantergebang di Bekasi), dan kampanye sosialisasi kebersihan dan daur ulang limbah.

\section{b. Pengolahan limbah cair di hilir}

Pengolahan limbah cair di hilir direncanakan akan menggunakan sistem pengolahan limbah cair dengan teknologi pengolahan biologi yang disebut FCR (Food Chain Reactor). Kelebihan FCR jika dibandingkan dengan teknologi pengolahan air limbah konvensional (lumpur aktif) adalah teknologi ini memiliki volume reaktor yang lebih kecil sehingga kebutuhan lahannya lebih sedikit, waktu retensi yang lebih singkat, menambahkan unsur estetika, tidak berbau, pengolahan yang lebih efisien karena pemantauan dapat dilakukan secara digital.

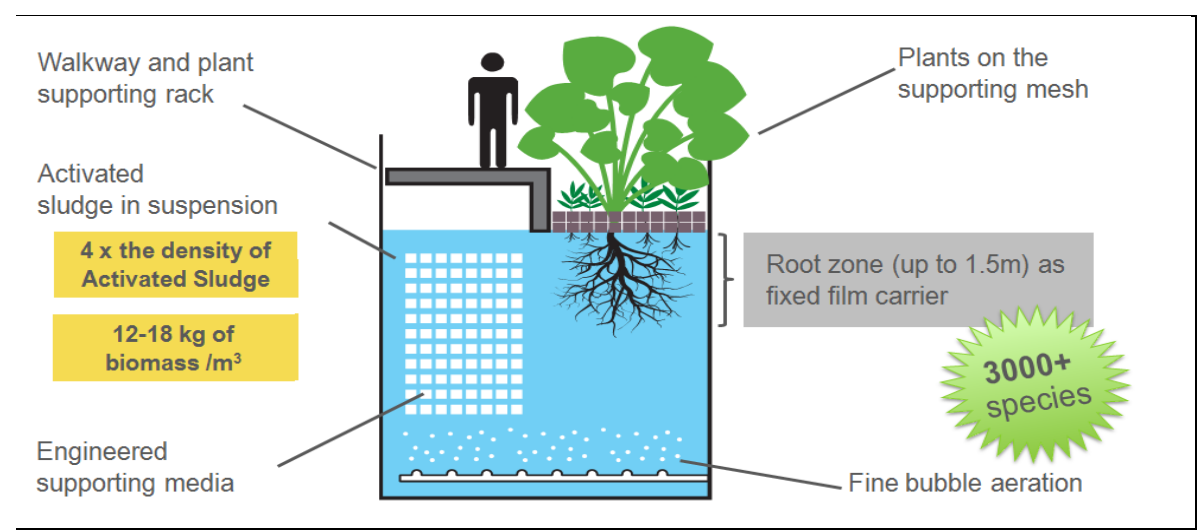

Gambar 2. Biomodul Food Chain Reactor (FCR)

Sumber: PT. Organica Water Solutions

Gambar 2. menunjukkan penampang depan dari biomodul FCR. Biomodul ini terdiri dari tanaman yang akarnya berfungsi sebagai tempat berkembang biak mikroorganisme begitu pula dengan artifisial media yang dimanfaatkan untuk menambah area perkembangbiakan mikroorganisme. Selain itu, reaktor ini memiliki sistem aerasi di dasarnya untuk suplai oksigen untuk mikroorganisme. Dalam satu 
Angga Sukmara Christian Permadi, Chaikal Amrullah, Frieda Astrianty Hazet, Unika Merlin Sianturi, dan Abdul Malik Sadat Idris

reaktor diperkirakan akan hidup kurang lebih 3000 spesies dengan konsentrasi biomassanya adalah $12-18 \mathrm{~kg} / \mathrm{m}^{3}$.

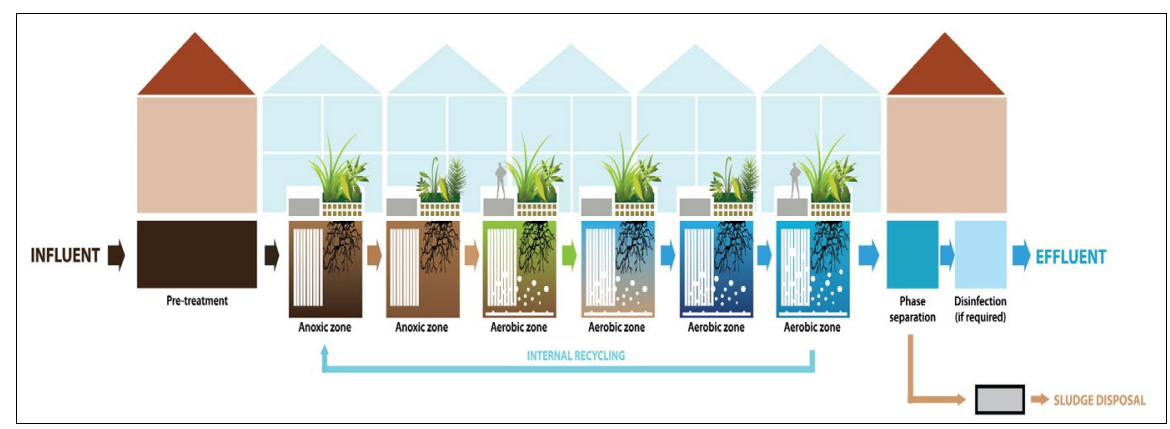

Gambar 3. Konfigurasi Pengolahan Air Limbah Konsep Organica Sumber: PT. Organica Water Solutions

Gambar 3. menunjukkan konfigurasi pengolahan air limbah dari konsep Organica. Sebelum air limbah masuk ke dalam FCR, air limbah akan melalui pretreatment yang terdiri dari coarse screen, fine screen, dan gritt removal. Setelah melalui pre-treatment, air akan masuk ke dalam FCR yang terdiri dari 6 zona. Selanjutnya, air hasil olahan dari FCR akan masuk ke dalam tangki sedimentasi (phase separation) yang berfungsi untuk memisahkan sedimen dan air bersih hasil olahan. Air bersih hasil olahan tersebut dapat langsung disalurkan ke kolam penampung air bersih atau jika diperlukan dapat ditambahkan disinfektan untuk membunuh bakteri patogen dalam tangki disinfeksi. Sedangkan lumpur yang dihasilkan dari tangki sedimentasi akan masuk ke dalam pengolahan lumpur filter press.

\subsection{Teknologi Water Recycle untuk Peningkatan Kualitas Air}

Upaya mendaur ulang air limbah merupakan salah satu upaya menangani kekurangan air dan perlindungan lingkungan pesisir. Penggunaan daur ulang air limbah/reklamasi air dapat digunakan untuk berbagai keperluan antara lain untuk irigasi pertanian atau lanskap, penggunaan industri, recharge air tanah, dan untuk keperluan suplai air bersih serta untuk keperluan umum misalnya untuk flushing dan untuk air pemadam kebakaran dan lain-lain. Penelitian penerapan teknologi daur ulang di kawasan pesisir adalah penting untuk dikaji, sehingga dapat dipertimbangkan sebagai alternatif teknologi daur ulang sesuai karakteristik lokasi pesisir dan tujuan daur ulang air limbah yang ingin dicapai. Penerapan teknologi pengolahan air limbah dilakukan dengan rangkaian sistem yang terdiri dari sistem biofilm anaerobik - media jaring ikan dan batok kelapa, hybrid constructed wetland/ lahan basah buatan dan saringan pasir lambat tipe aliran upflow. Penerapan teknologi daur ulang yang efektif diharapkan dapat mendukung adaptasi wilayah pesisir dalam menghadapi masalah krisis air, pemenuhan air untuk kebutuhan umum rumah tangga, kebutuhan pengisian air tanah untuk mencegah intrusi air laut dan pengendalian kerusakan ekosistem akibat pembuangan air limbah yang tidak terkendali (Hastuti dkk 2013).

Berikut ini adalah dua contoh daur ulang air yang diterapkan di dua Negara yang berbeda. 
Angga Sukmara Christian Permadi, Chaikal Amrullah, Frieda Astrianty Hazet, Unika Merlin Sianturi, dan Abdul Malik Sadat Idris

\section{Orange County Water District (OCWD)}

OCWD melakukan program pengelolaan sumber daya air di bagian Selatan California dengan cara menjaga cekungan air tanah di distrik Orange County, melakukan konservasi air di DAS Santa Ana, menerapkan sistem pengisian air tanah (Ground Water Replenishment System - GWRS) dan melindungi Orange County secara hukum atas hak Sungai Santa Ana. Orange County Water District, California menerapkan" ecosystem services" untuk mengelola cekungan air tanah yang dimanfaatkan untuk penyediaan air di 19 kota. Cekungan air tanah Orange County memiliki kapasitas operasional air baku sekitar 616,7 juta $\mathrm{m}^{3}$ per tahun dan luasannya mencakup 69.930 ha. Kapasitas tersebut mampu menyediakan sekitar $75 \%$ kebutuhan air minum untuk 2,5 juta penduduk. Sungai Santa Ana merupakan sungai terbesar di California Selatan yang dimulai dari Pegunungan San Bernadino dan mengalir ke hilir Bendungan Prado ke Orange County, dan berlanjut ke Samudra Pasifik. OCWD melakukan pengelolaan DAS Santa Ana yang mempunyai Panjang $9,7 \mathrm{~km}$. Karena aliran sungai dipengaruhi oleh penggunaan air di bagian hulu dan fluktuasi cuaca, air baku dari DAS Santa Ana kurang dapat diandalkan dibandingkan dengan pasokan air lainnya. Ground Water Replenishment System (GWRS) merupakan joint project Orange County Water District (OCWD) dan Orange County Sanitation District (OCSD). Orange County Sanitation District (OCSD) merupakan public agency yang menyediakan fasilitas untuk pengumpulan air limbah, melakukan pengolahan dan daur ulang menggunakan advanced water treatment technology. OCSD melayani timbulan air limbah di sebanyak 20 kota. OCSD memiliki dua fasilitas operasi yang berfungsi untuk mengolah air limbah dari perumahan, kawasan komersial dan industri. Air limbah ini dialirkan melalui saluran pembuangan sepanjang 396 mil dan berakhir di Fountain Valley atau Huntington Beach yang merupakan fasilitas pengelolaan air limbah. Hasil olahan air limbah tersebut akan dikirim untuk di daur ulang atau dilepaskan ke Samudera Pasifik selain itu juga berfungsi untuk menyediakan pasokan air yang ditambahkan ke cekungan air tanah Orange County dan dapat diinjeksikan ke dalam coastal barrier well untuk menjaga air laut meluap dari cekungan. Sistem ini dapat menyediakan kebutuhan air saat musim kemarau.

Pengelolaan air tanah yang dilakukan di Orange County terdiri dari tiga cara utama, diantaranya:

\section{- Recharge}

OCWD mengambil air permukaan dari beberapa sumber menggunakan inflatable rubber dams, bangunan tanggul air, penampungan air hujan ke dalam kolam recharge. Air di kolam recharge perlahan bermigrasi ke cekungan air tanah. Sedangkan untuk recycled water ditampung di kolam recharge Anaheim dengan panjang pipa 13 mil dari GWRS.

\section{- Monitor}

OCWD memonitor, melindungi kualitas air dan mempertahankan water level di kolam. Menjaga air tanah dari kontaminan sehingga mencegah terjadinya intrusi air laut. Selain itu, program monitoring juga dilakukan dalam bentuk pemantauan dan pengujian air tanah, air kolam dan air olahan agar tidak terkontaminasi bahan kimia berbahaya. OCWD juga memantau kualitas sumur air minum untuk kebutuhan air ritel di seluruh Orange County. 
Angga Sukmara Christian Permadi, Chaikal Amrullah, Frieda Astrianty Hazet, Unika Merlin Sianturi, dan Abdul Malik Sadat Idris

\section{- Purify}

OCWD melakukan pengolahan air limbah dari Orange County Sanitation District dan sistem pemurnian air di GWRS dengan menggunakan Advanced Water Treatment (microfiltration, reverse osmosis dan sinar UV dengan hydrogen peroksida). Dengan proses tersebut akan didapatkan air dengan kualitas tinggi yang baku mutunya telah melebihi standar air minum di California. Hasil air olahan di injeksikan ke dalam seawater barrier dan di pompa untuk mengisi kolam recharge sehingga dapat meresap ke cekungan air tanah Orange County dan dapat dimanfaatkan untuk persediaan air minum. Orange County district juga memurnikan air secara alami melalui teknologi wetland di sepanjang daerah tepi sungai Santa Ana.

Sumber utama air baku yang ditampung di kolam meliputi aliran air dari Sungai Santa Ana, curah hujan tinggi yang berasal dari musim dingin, reused water, Sungai San Joaquin dan Sungai Colorado.

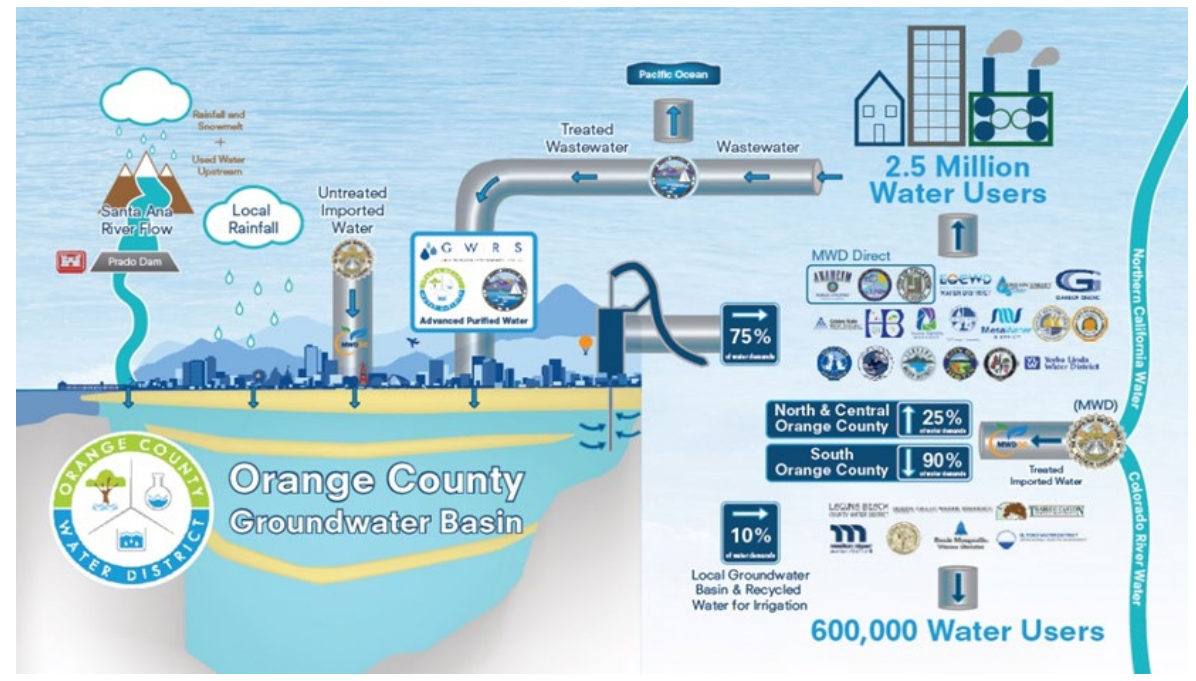

Gambar 4. Pengelolaan Sumber Daya Air di Orange County

Sumber: www.ocwd.com

Advanced Water Treatment Facility pada sistem GWRS yang digunakan di Orange County beroperasi sejak Januari 2008 dan dapat memproduksi air hasil olahan sekitar $378.000 \mathrm{~m}^{3} /$ hari. Sebanyak $70 \%$ air hasil olahan dipompa untuk disalurkan ke kolam yang berada di daerah Kraemer, Miller dan Miraloma sedangkan 30\% nya disalurkan ke sumur injeksi di sepanjang seawater intrusion barrier. Air limbah yang akan dimurnikan di sistem GWRS harus melakukan pre-treatment yang sangat ketat dimana kontrol dan pengolahannya dioperasikan dan dikelola oleh OCSD. Pengolahan tersebut meliputi preliminary treatment, primary treatment dan secondary treatment).

Preliminary treatment merupakan langkah awal dalam meminimalisir air limbah dari beberapa kontaminan ukuran besar seperti batu, sampah padat dan material padat lainnya. Maka dari itu digunakan barscreen dan grit chambers agar material padat maupun halus dapat tersisihkan dalam proses ini sehingga tidak mengganggu kinerja pompa. By product dari unit pengolahan tersebut langsung 
Angga Sukmara Christian Permadi, Chaikal Amrullah, Frieda Astrianty Hazet, Unika Merlin Sianturi, dan Abdul Malik Sadat Idris

disalurkan melalui TPA (Tempat Pembuangan Akhir) berupa landfill. Setelah itu air limbah masuk ke unit clarifier (primary treatment) yang berfungsi untuk mengendapkan padatan organik, oil and grease dan kontaminan lainnya. Setelah itu materi yang terendapkan masuk kedalam proses digester. Setelah itu dilakukan penyisihan air limbah dari bahan organik terlarut dalam proses secondary treatment. Unit pengolahan yang dapat digunakan yaitu activated sludge, tricking filters, clarifiers dan banyak teknologi lainnya dimana memanfaatkan aktivitas biologis untuk memecah bahan organik. By product dari proses biologis tersebut dapat dimanfaatkan untuk menggemburkan tanah di lahan pertanian daerah Arizona. Setelah melalui beberapa tahapan pengolahan air limbah, maka kualitas dair air tersebut meningkat kemudian dimurnikan di sistem GWRS menjadi air siap minum.

\section{NEWater Singapura}

Pasokan air Singapura saat ini berasal dari empat sumber utama, yaitu, air dari tangkapan lokal, impor dari Malaysia, NEWater dan air desalinasi. Daerah tangkapan air lokal terdiri dari 17 reservoir dan jaringan kolam pengumpul air hujan yang membantu mencegah banjir selama curah hujan yang tinggi. Pada tahun 2011, daerah resapan air telah meningkat dari setengah menjadi dua pertiga dari permukaan tanah Singapura. Serangkaian saluran pipa dibangun sehingga kelebihan air dapat dipompa dari satu reservoir ke reservoir lainnya untuk penyimpanan. Singapura akan meningkatkan jumlah reservoirnya melalui Reservoir Integration Program. Pada saat yang sama, teknologi membran canggih akan memungkinkan Public Utilities Board (PUB) untuk melakukan berbagai kegiatan di daerah tangkapan air tanpa mengurangi kualitas air reservoir. PUB adalah dewan hukum Singapura dari Kementerian Lingkungan Hidup dan Sumber Daya Air yang bertanggung jawab untuk memastikan pasokan air yang berkelanjutan dan efisien. PUB mengatur dan mengawasi seluruh sistem pasokan air negara, yang terdiri dari sistem resapan air, sistem drainase, pekerjaan air, pabrik reklamasi air, dan sistem pembuangan limbah.

Bagi Singapura, air bekas pemakaian bisa menjadi sumber daya untuk diolah kembali menjadi air bersih. Pengolahan air bekas pemakaian menggunakan teknologi membran canggih dan ultraviolet yang disebut NEWater. Air yang dihasilkan pun kembali murni, bahkan sangat murni. Oleh karena itu, sebagian besar air hasil NEWater ini biasanya disalurkan ke pabrik-pabrik yang membutuhkan air murni. Sisanya dicampur dengan air dari reservoir, lalu diolah kembali dan didistribusikan ke masyarakat untuk siap diminum.

Saat ini, Water Reclamation Plant (WRP) di Singapura dapat mengolah $800.000 \mathrm{~m}^{3}$ air kotor perhari untuk kebutuhan industri dan air minum. NEWater saat ini memasok 30\% dari kebutuhan air nasional, dan pada 2060 Singapura berencana untuk melipatgandakan kapasitas NEWater saat ini untuk menyediakan hingga 55\% dari kebutuhan air di masa depan. Proses pengolahan NEWater terdiri 3 tahap yaitu:

\section{- Tahap 1 - Tahap Pertama}

Tahap pertama proses produksi NEWater dikenal sebagai Mikrofiltrasi (MF). Dalam proses ini, air kotor yang diolah dilewatkan melalui membran untuk menyaring dan menahan permukaan padatan tersuspensi, partikel koloid, bakteri penyebab penyakit, beberapa virus dan kista protozoa. Air yang disaring yang melewati membran hanya mengandung garam terlarut dan molekul organik. 
Angga Sukmara Christian Permadi, Chaikal Amrullah, Frieda Astrianty Hazet, Unika Merlin Sianturi, dan Abdul Malik Sadat Idris

\section{- Tahap 2 - Reverse Osmosis}

Tahap kedua dari proses produksi NEWater dikenal sebagai Reverse Osmosis (RO). Dalam RO, membran semi-permeabel digunakan. Membran semipermeabel memiliki pori-pori sangat kecil yang hanya memungkinkan molekul sangat kecil seperti molekul air untuk melewatinya. Akibatnya, kontaminan yang tidak diinginkan seperti bakteri, virus, logam berat, nitrat, klorida, sulfat, produk sampingan desinfeksi, hidrokarbon aromatik, pestisida dll, tidak dapat melewati membran. Oleh karena itu, NEWater adalah air RO dan bebas dari virus, bakteri dan mengandung jumlah garam dan bahan organik yang dapat diabaikan.

\section{- Tahap 3 - UV Disinfeksi}

Pada tahap ini, air sudah memiliki kualitas air bermutu tinggi. Tahap ketiga dari proses produksi NEWater ini benar-benar bertindak sebagai tahap tambahan untuk memastikan air benar-benar aman dari bakteri-bakteri patogen.

\section{- Penetralan $\mathrm{pH}$}

Dengan penambahan beberapa bahan kimia alkali untuk mengembalikan keseimbangan asam-alkali atau pH, NEWater kini siap disalurkan ke berbagai aplikasi.

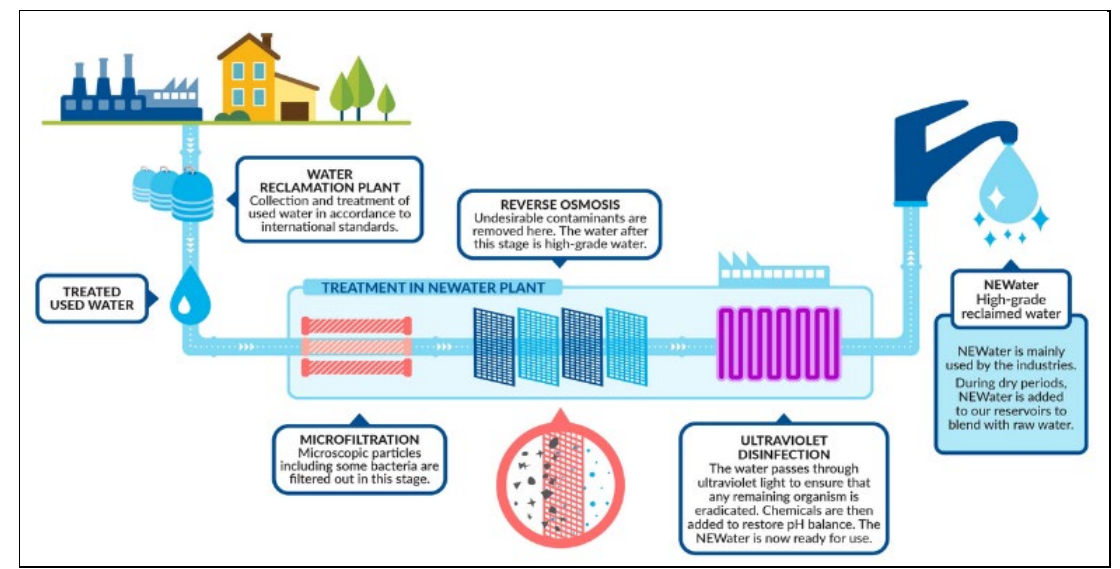

Gambar 5. Proses water recycle NEWater di Singapura

Sumber: https://www.pub.gov.sg/watersupply/fournationaltaps/newater

Air hasil olahan dari proses-proses tersebut telah diuji baik uji fisik, kimia, dan mikrobiologi komprehensif yang menunjukkan bahwa kualitas NEWater secara konsisten melebihi baku mutu yang ditetapkan oleh USEPA (United States Environmental Protection Agency) dan WHO (World Health Organization). Melalui proses-proses tersebut, NEWater adalah air yang sangat bersih dan aman untuk diminum. 
Angga Sukmara Christian Permadi, Chaikal Amrullah, Frieda Astrianty Hazet, Unika Merlin Sianturi, dan Abdul Malik Sadat Idris

\subsection{Pengembangan Wilayah}

\subsubsection{Perolehan Daratan Baru}

Dalam rangka pengembangan wilayah, kebutuhan akan lahan menjadi salah satu isu utama. Pada konsep pembangunan berkelanjutan di Teluk Jakarta, pembangunan waduk lepas pantai membuka potensi perolehan daratan baru melalui penurunan muka air waduk. Perolehan daratan baru tersebut berbeda dengan konsep perolehan daratan pada umumnya. Umumnya, daratan baru diperoleh dengan melakukan urugan pada area yang ingin dijadikan daratan baru. Sumber material urug diperoleh dengan mengeksploitasi ekosistem di hulu dan juga ekosistem laut yang dapat menyebabkan kerusakan lingkungan apabila pengambilan material urug tidak dilakukan ditempat yang tepat dan dengan teknologi yang tepat. Konsep pembangunan Waduk Lepas Pantai dapat memperoleh daratan baru tanpa melakukan pengurugan. Setelah struktur tanggul lepas pantai selesai dibangun, muka air akan diturunkan sampai dengan $-5 \mathrm{~m}$ sehingga diperoleh daratan baru sekitar 9.000 Ha. Daratan yang diperoleh bisa dikembangkan untuk menjadi permukiman, kampung nelayan, dan pengembangan pusat pemerintahan.

\subsubsection{Pemanfaatan dan Pengelolaan Daratan Baru}

Daratan baru yang didapatkan dari pembangunan tanggul lepas pantai dapat dimanfaatkan untuk berbagai macam pengembangan, diantaranya:

\section{Perumahan}

Berdasarkan data yang diperoleh dari Pusat Pengelolaan Dana Pembiayaan Perumahan (PPDPP), pada tahun 2015 angka backlog di DKI Jakarta mencapai 1.276.424. Salah satu penyebabnya adalah karena sempitnya lahan sehingga mengakibatkan naiknya harga tanah. Hal ini mengakibatkan masyarakat kesulitan untuk memperoleh lahan dengan harga yang terjangkau. Dengan metode menurunkan muka air laut untuk mendapatkan lahan baru, diharapkan dapat mengurangi biaya dalam proses mendapatkan lahan tersebut sehingga lahan yang didapat harganya lebih murah. Dengan demikian, lahan tersebut semakin terjangkau dan dapat dimanfaatkan sebagai perumahan.

\section{Pusat Pemerintahan}

Sama halnya dengan kebutuhan lahan untuk pengembangan perumahan, kebutuhan lahan untuk pengembangan pusat pemerintahan juga sangat diperlukan. Kondisi DKI Jakarta yang sudah menjadi pusat pemerintahan serta semakin terbatasnya lahan membuat kebutuhan lahan untuk pengembangan pusat pemerintahan menjadi suatu kebutuhan tersendiri. Tanah timbul yang akan diperoleh pada konsep waduk lepas pantai diharapkan dapat dimanfaatkan salah satunya sebagai pengembangan pusat pemerintahan. Selain itu, hal ini dapat menjadi pilihan alternatif dalam pertimbangan pemindahan ibukota.

\section{Pengembangan Infrastruktur}

Untuk pengembangan kedepan, tanah timbul yang diperoleh pada konsep waduk lepas pantai juga dapat digunakan sebagai pengembangan infrastruktur seperti bandara dan pelabuhan. Pembangunan bandara baru di Jakarta dapat menjadi alternatif untuk mengurangi kepadatan trafik di Bandara Internasional Soekarno Hatta. Selain itu, penambahan lahan baru juga dapat dimanfaatkan untuk pengembangan Pelabuhan Tanjung Priok. 
Angga Sukmara Christian Permadi, Chaikal Amrullah, Frieda Astrianty Hazet, Unika Merlin Sianturi, dan Abdul Malik Sadat Idris

\subsubsection{Penanggulangan Dampak Sosial Terhadap Kehidupan Nelayan}

Tanggul Lepas Pantai yang rencananya akan dibangun, harus tetap menyediakan akses nelayan menuju laut lepas untuk menjamin kelancaran melaut. Terdapat 5 TPI (Tempat Pelelangan Ikan), 1 PPI (Pelabuhan Perikanan), dan 1 PPS (Pelabuhan Perikanan Samudera) yang berkaitan langsung dengan tanggul lepas pantai PTPIN (Pengembangan Terpadu Pesisir Ibukota Negara). TPI, PPI dan PPS dimaksud diantaranya TPI Tanjung Pasir (1.759 Nelayan), TPI Dadap (1.422 Nelayan, 1.903 Kapal), TPI Muara Kamal (268 Nelayan, 197 Kapal), PPI Muara Angke (20.553 Nelayan, 1.543 Kapal), PPS Nizam Zachman (6.002 Nelayan, 1.330 Kapal), TPI Kalibaru (1.296 Nelayan, 462 Kapal), dan TPI Cilincing (494 Nelayan, 168 Kapal). PPS Nizam Zachman, sesuai dengan rencana Kementerian Kelautan dan Perikanan, akan dikembangkan menjadi NFC (National Fisheries Centre). Rencana pengembangan NFC ini juga harus terakomodir dalam konsep waduk lepas pantai.

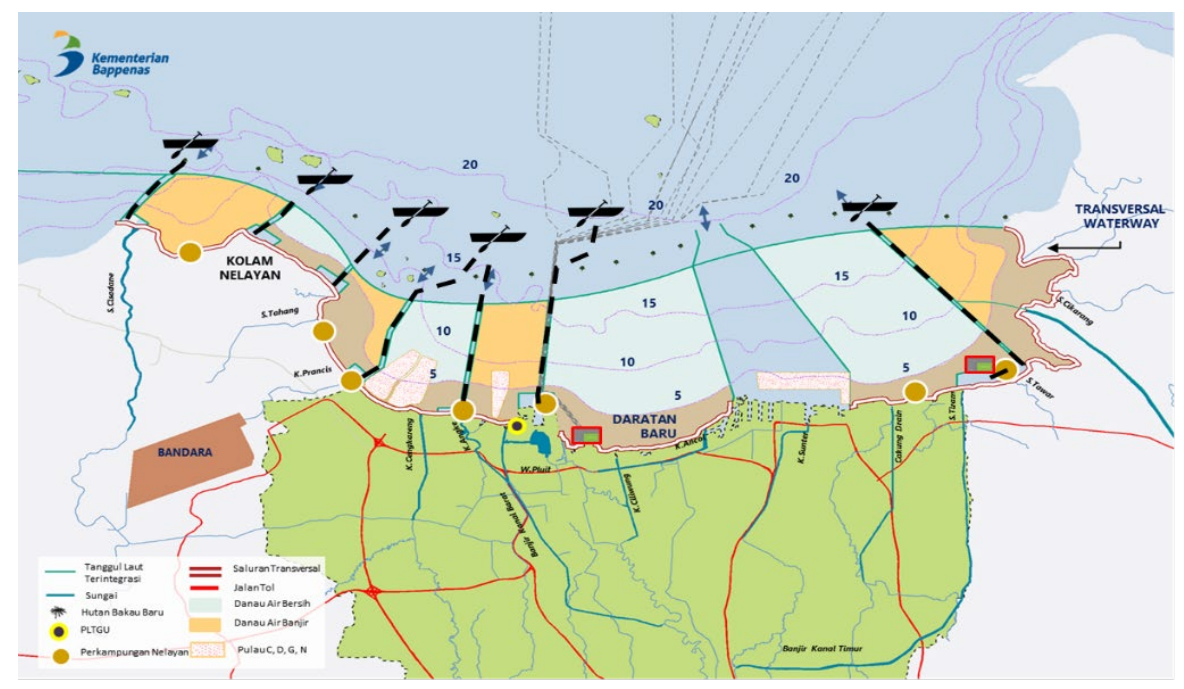

Gambar 6. Rencana Akses Nelayan ke Laut

Sumber: Direktorat Pengairan dan Irigasi Bappenas

Pemukiman nelayan di Teluk Jakarta terkonsentrasi di Dadap, Kamal Muara, Muara Angke, Muara Baru, Cilincing, Marunda, Kalibaru, Koja, dan Lagoa. Pemukiman kumuh nelayan perlu direvitalisasi dan ditata kembali. Pemukiman nelayan yang berada di wilayah kritis, perlu direlokasi ke tempat yang lebih aman. Relokasi nelayan harus juga menyertakan aktivitas lain yang ada di belakangnya. Relokasi dilakukan secara berkelompok dengan memperhatikan relasi jaringan sosial nelayan yang ada sekarang. Pada masa transisi, pemerintah diharapkan dapat menyediakan pendampingan, pelatihan, menyediakan alternatif mata pencaharian sementara, menyediakan tempat sementara, serta menyediakan kredit bagi nelayan.

Untuk merelokasi pemukiman nelayan, Pemerintah DKI Jakarta telah menyiapkan beberapa lokasi pemukiman nelayan yang baru dalam bentuk rumah susun tematik yang diperuntukkan bagi nelayan. Rencananya rumah susun tematik akan dibangun di beberapa lokasi, yaitu Muara Angke, Muara Baru, Kali Baru, Cilincing, Marunda, dan Kamal Muara. Selain itu, pemerintah DKI juga menyiapkan Pulau Tidung Kecil di Kepulauan Seribu untuk nelayan. Lokasi rumah susun 
Angga Sukmara Christian Permadi, Chaikal Amrullah, Frieda Astrianty Hazet, Unika Merlin Sianturi, dan Abdul Malik Sadat Idris

berdekatan dengan pantai dan fasilitas TPI/PPI sehingga tidak mengganggu mata pencaharian nelayan. Selain itu pemerintah juga mempunyai rencana untuk mengembangkan satu atau sebagian dari pulau reklamasi untuk pengembangan sentra perikanan terpadu yang juga disertai dengan pemberdayaan ekonomi bagi nelayan.
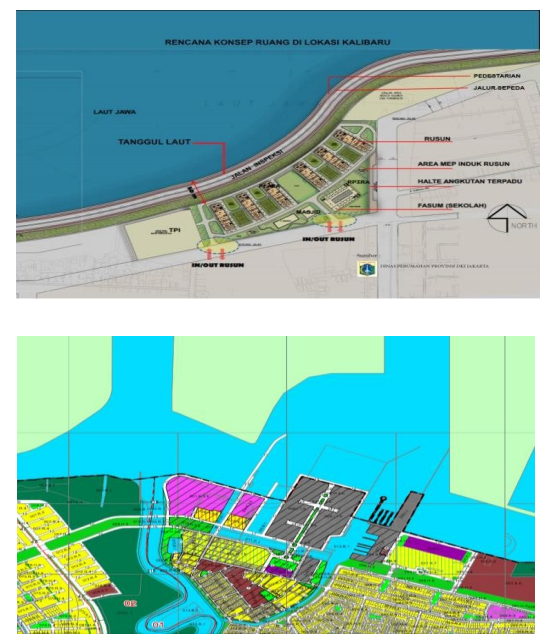

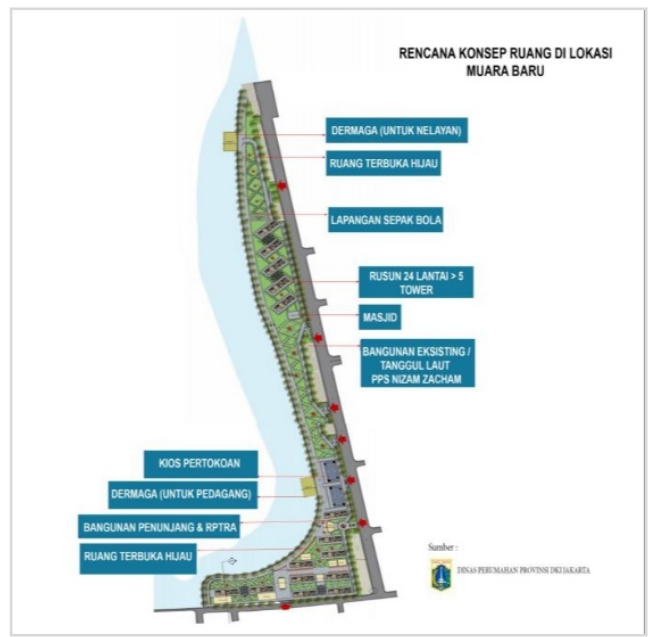

Gambar 7. Rencana konsep penataan pemukiman nelayan di Muara Baru, Kali Baru, dan Muara Angke

Sumber: Ditjen SDA Kementerian PUPR, 2017

Untuk pemukiman nelayan yang tidak direlokasi, pembangunan waduk lepas pantai diintegrasi dengan penataan pemukiman nelayan existing. Dengan revitalisasi pemukiman nelayan, desa-desa menjadi lebih tertata, nyaman dan tidak kumuh. Dengan lingkungan yang bersih diharapkan kualitas kesehatan dan kenyamanan nelayan meningkat. Pembangunan rumah singgah dapat menjadi salah satu solusi untuk mengatasi permasalahan nelayan pendatang.

\section{Kesimpulan}

Pembangunan Tanggul Lepas pantai di pesisir utara Jakarta akan memberikan Ruang Terbuka Biru (RTB) dan Ruang Terbuka Hijau (RTH) bagi Kota Jakarta, sebagian Banten, dan sebagian Jawa Barat. Lahan hasil penurunan muka air waduk yang tercipta, dapat ditata dan dimanfaatkan untuk mengurangi tekanan pada daratan dan RTH existing di Jakarta. Dalam perencanaan waduk lepas pantai, mangrove eksisting akan tetap dipertahankan keberadaannya. Selain itu pembangunan tanggul ini juga akan menciptakan green belt-hutan mangrove baru di sepanjang sisi luar tanggul lepas pantai maupun di daerah kanal nelayan dengan luas tambahan mangrove baru sebesar 352 Ha. Hutan mangrove ini diharapkan dapat berkontribusi pada penambahan lahan RTH DKI Jakarta, Banten dan Jawa Barat. Hutan mangrove ini diharapkan dapat menjadi ekosistem bagi hewan-hewan yang bermigrasi dan rumah bagi spesies yang dulu pernah ada dan diharapkan dapat kembali ada lagi. Sabuk hijau ini juga akan berfungsi sebagai salah satu tembok pertahanan tanggul lepas pantai dari terpaan gelombang laut lepas secara langsung.

Tanggul lepas pantai akan menciptakan waduk lepas pantai yang dapat dimaksimalkan kegunaannya sebagai danau air tawar. Waduk lepas pantai yang terbentuk akan menyumbang \pm 24.500 ha untuk luasan RTB di Jakarta, Banten, dan 
Angga Sukmara Christian Permadi, Chaikal Amrullah, Frieda Astrianty Hazet, Unika Merlin Sianturi, dan Abdul Malik Sadat Idris

Jawa Barat. Semakin luas RTB di Teluk Jakarta, semakin luas penampang air yang dapat menampung limpahan air dikala banjir dan banyak cadangan air yang dapat digunakan disaat kekeringan. Untuk memaksimalkan manfaat tanggul lepas pantai ini, RTH dan RTB perlu dikelola secara berkelanjutan. Dengan begitu masyarakat tidak hanya memiliki kesempatan untuk mengonservasi sumber daya air dan keragaman hayati yang ada tetapi juga dapat meningkatkan serapan karbon, menjaga efek pendinginan udara setempat, hingga bisa mengelola sumber daya air sebagai sumber tenaga listrik terbarukan, bahkan dapat menjaga keindahan bentang alam yang sudah sepatutnya dinikmati."

\section{Referensi}

Decathlon. 2018. Pengelolaan Das Perkotaan Jabodetabekpunjur.

Direktorat Pengairan dan Irigasi Kementerian Perencanaan Pembangunan Nasional / Badan Perencanaan Pembangunan Nasionan (Kementerian $\mathrm{PPN} /$ Bappenas)

Ditjen SDA (Sumber Daya Air) Kementerian PUPR (Pekerjaan Umum dan Perumahan Rakyat), 2017.

Hammer, D.A. (ed). 1989. Constructed Wetlands for WastewaterTreatment: Municipal, Industrial and Agricultural. Chelsea, Michigan: Lewis Publishers,Inc.

Hastuti dkk. 2013. Daur Ulang Air Limbah Rumah Tangga dengan Teknologi Biofilter dan Hybrid Constructed Wetland di Kawasan Pesisir. Badan Litbang Kementerian Pekerjaan Umum.

https://www.pub.gov.sg/watersupply/fournationaltaps/newater

(Diakses Februari 2019)

https://www.ocwd.com/ (Diakses pada Februari 2019)

Krueger, Richard A. 1988. FOCUS GROUPS: A Practical Guide for Applied Research. California: SAGE Publications.

Lehoux, P., Poland, B., \& Daudelin, G. 2006. Focus group research and "the patient's view." Social Science \& Medicine, 63, 2091-2104.

Oragnica Water. 2017. "Reference List".

https://d3o1jlvchszf6h.cloudfront.net/Organica_Water_Reference_List \%202017Sept 13.pdf (Diakses pada 21 Desember 2018).

Organica Water. 2018. "Organica Water Company Overview". https://klearn.adb.org/system/files/materials/2018/05/201805-organicapowered-wastewater-treatment-plant.pdf (Diakses pada 21 Desember 2018).

Ray, C. and Jain, R. 2011. Drinking Water Treatment - Focussing on Appropriate Technologies and Sustainability. Springer.

Rosaline S. Barbour and Jenny Kitzinger (ed). 1999. Developing Focus Group Research: Politics, Theory and Practice. London: Sage Publications.

Vymazal J., Brix H., Cooper P.F., Green M.B., Haberl R. 1998. Constructed Wetlands for Wastewater Treatment in Europe. Leiden: Backhuys Publishers. 